\title{
Duygusal Zeka, Kariyer Uyumu ve Yaşam Doyumu Arasındaki İlişkiler: Turizm Sektörü Çalışanları Üzerine Bir Araştırma \\ (The Relationships Between Emotional Intelligence, Career Adaptation and Life \\ Satisfaction: A Research on the Employees Working in Tourism Sector)
}

\section{Emrah KESKIN iD a Özgür YAYLA iD b Ferzan AKTAŞ iD c}

a Hacı Bektaş Veli Üniversitesi, Turizm Fakültesi, Gastronomi ve Mutfak Sanatları Bölümü, Nevşehir, Türkiye. ekeskin@nevsehir.edu.tr

b Akdeniz Üniversitesi, Manavgat Turizm Fakültesi, Rekreasyon Yönetimi Bölümü, Antalya, Türkiye. ozguryayla@akdeniz.edu.tr

c Hacı Bektaş Veli Üniversitesi, Sosyal Bilimler Enstitüsü, Nevşehir, Türkiye. ferzanaktas76@gmail.com

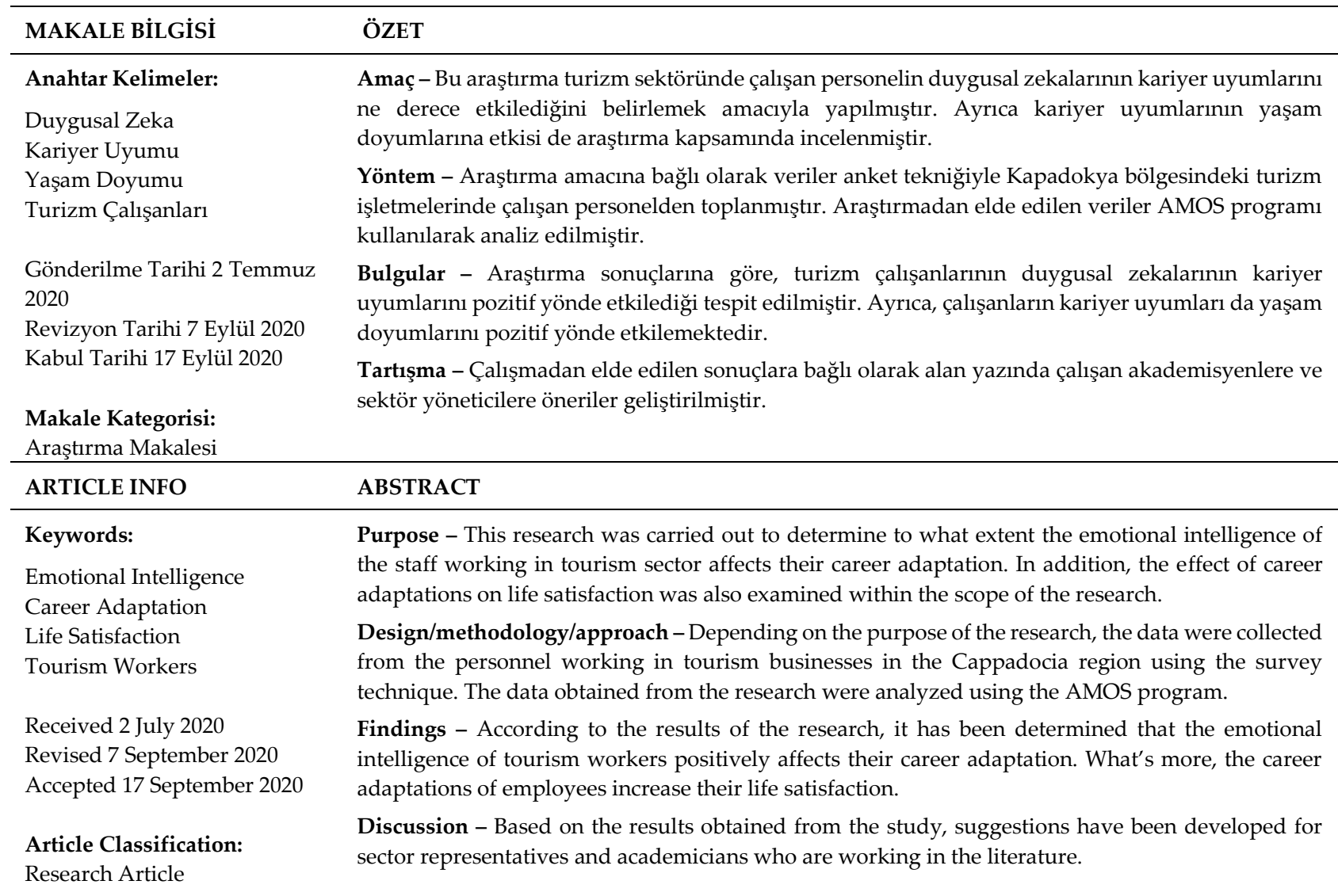

\section{GíRiş}

Geçmişten günümüze kadar süregelen zamanda duygular, insan yaşamının mutlak ve ayrılmaz bir parçası olmuştur. Bu konuda, geçen yıllar içerisinde gerçekleşen akıl-duygu çatışmaları birtakım tartışmaları da beraberinde getirmiştir. Akıl-duygu karmaşasının yaratmış olduğu buhranlı alan duygusal zeka çalışmalarının da zaman içerinde daha önemli bir hale gelmesini sağlamıştır (Yan, 2008). Duygusal zeka, kişinin kendisini motive edebilmesi, sorunlarla duygularını yöneterek kolaylıkla başa çıkabilmesi, sosyal gelişim becerilerini artırması açısından önemlidir. Duygusal zeka düzeyi yüksek kişilerin çevresiyle daha rahat iletişim kuran, sosyal çevrelerinde benimsenen, iş yaşamında başarısı yüksek kişiler olduğu tespit edilmiştir (Doğan ve Demiral, 2007). Çalışanların duyguları anlamlandırma seviyelerinin yüksek olması, olayları daha iyi yorumlama becerisini ortaya çıaracağı için iş yaşamındaki hayal kırıklığı ve stresi azaltmada

\section{Önerilen Atıf/ Suggested Citation}

Keskin, E., Yayla, Ö., Aktaş, F. (2020). Duygusal Zeka, Kariyer Uyumu Ve Yaşam Doyumu Arasındaki İlişkiler: Turizm Sektörü Çalışanları Üzerine Bir Araştırma, İşletme Araştırmaları Dergisi, 12 (3), 2985-2995. 
etkili rol oynayabilmektedir. Aynı zamanda bu durum grup olarak çalışılan ortamlarda olumlu etkileşimleri artırarak diğer kişilerin motivasyon seviyesini de olumlu yönde etkileyebilmektedir. Çalışanların duygusal alanı iyi bir şekilde değerlendirmesi kendilerine karşı olan memnuniyet düzeylerini artırarak iş doyumunun daha fazla ortaya çıkmasına katkı sağlamaktadır. İş doyumu, işten duyulan memnuniyet ve tatmin duygusu daha fazla olan çalışanlarda işletmeye karşı sadakat duygusu yaşanmaktadır (Sy, vd., 2006; Ergün ve Boz, 2017).

Duygusal zeka kavramının tam olarak özümsenmesiyle birlikte zaman içerisinde duyguların bireyin davranışlarının merkezini oluşturduğu tespit edilmiş ve hizmet odaklı işletmelerde kariyer uyum sürecinde duygusal zekanın önemli bir yere sahip olduğu belirlenmiştir (Tanrıverdi, vd., 2019). Kişilerde duygusal zekanın yüksek olması zihinsel sağlı̆̆ı en üst seviyede tutarak, psikolojik yaşam refah seviyesini artırmaktadır. Bu durum kişilerin hayatlarında daha konforlu davranmalarını sağlayarak yaşamdan tatmin olma duygusunu ön plana çıkarabilmektedir (Wing, vd., 2006). Bunun yanında kariyer odaklı yapılan çalışmalar az fakat artan niteliktedir (Tuna, 2017; Kendir ve Özkoç, 2018; Vatansever Toylan ve Yılmaz, 2020; Arslan, 2020; Çeşmeci Çalışkan ve Özsoy, 2020). Özellikle hizmet odaklı sektörlerden birisi olan turizm sektöründe bireylerin dışa dönük, empati yeteneği yüksek, sorumluluk bilincine sahip kişilik özelliklerinde olması kariyer odaklı hedeflerini daha gerçekçi bir hale getirmektedir. Bu da kişilerin işten tatmin olma ve yaşam doyumuna ulaşmalarını sağlamaktadır (Temeloğlu ve Aksu, 2016). Bu nedenle turizm sektöründe çalışan kişilerin duygusal zeka seviyelerinin tanımlanması ve turizmde kariyer yapma isteğine etkisinin belirlenmesi, turizmde kariyer yapma arzusunun da yaşam doyumuna ne tür bir etkisinin olduğunun ortaya konulması önemli görülmektedir. Belirlenen bu önemden hareketle çalışmada Kapadokya bölgesinde turizm sektöründe çalışan kişilerin duygusal zeka, kariyer uyumu ve yaşam doyumları arasındaki ilişkiler incelenmiştir.

\section{LITERATÜR TARAMASI}

Duygu ve zeka kavramlarının temel olarak ele alınması binlerce yıllık bir felsefenin konusudur. İnsanlar rasyonel davranışlara meyilli canlılar olmalarının yanı sıra duygusal birtakım hisleri olan varlıklardır. Kişinin duygusal zeka faaliyetlerinin devamlılığı için dış olaylara açık kalması önemlidir. Duygular olmadan olayların değerlendirilmesi ve davranışa dönüştürülmesi mümkün değildir. Bu nedenle kişilerin duygularını anlamlandırabilmesinin hem günlük yaşantıda hem de iş yaşantısında önemli olduğu söylenebilir (Çakar ve Arbak, 2004). Duygular ve duygusal zeka kullanımı örgüt kültüründe de oldukça etkili olmaktadır. Örgüt kültürü içerisinde bireylerin olumlu bir duygu durumuna sahip olması, kariyerini geliştirmesinde ve iş performansını artırmasında etkidir (Ashkanasy, vd., 2002).

Duygusal zeka kavramını literatüre kazandıran Mayer ve Salovey (1990)'e göre bireyin ilk olarak kendi duygularının farkına varması daha sonraki aşamada duygularını yönetebilme becerisi kazanması ve diğer bireylerle iletişim kurabilir hale gelmesi buna bağlı olarak duygularını günlük yaşam içerisinde karşılaştığı zorlukları çözmede kullanması, duygusal zeka çalışmalarının temellerini oluşturmaktadır. İnsan yaşamının iş yaşamından ayrı olarak düşünülememesi zaman içerisinde duygusal zeka alanında yapılan çalışmaların iş yaşamına entegre edilmesinde etkili olmuştur.

Akçay ve Çoruk (2012) yapmış oldukları araştırmada, çalışma yaşamında duyguların yönetimini incelemişlerdir. Çalışmada duyguların yaşantı üzerindeki etkisine ve çalışma ortamında yarattığı duygusal emek algısına odaklanılmıştır. Elde edilen bulgular dahilinde tıpkı bireylerde olduğu gibi örgütlerde de duygusal alanın iyi yönetilmesi gerektiği, iyi bir yönetim sonucunda örgütlerde duygusal başarının artırılacağı sonucuna ulaşılmıştır. Duygusal başarısı artan bireyler iş ve kariyer yaşamına odaklılık gibi bir takım olgularda daha gerçekçi hedefler belirleyerek başarıya ulaşırlar. Cote ve Miners (2006) duygusal zeka, bilişsel zeka ve iş performansını bir arada inceledikleri bir çalışmayı literatüre kazandırmışlardır. Elde edilen bulgular duygusal zekanın iş performansı ve kariyer odaklılıkla doğrudan ilgili olduğunu ortaya koymuştur. Duygusal zekası yüksek bireyler duyguları doğru bir şekilde tanımlayıp anlayabildikleri için iş yaşamı içerisinde kariyer hedeflerine daha rahat bir şekilde ulaşma fırsatı yakalar. Duygusal zekası yüksek, işi yürütme becerisine sahip, kariyer odaklı hedefleri olan bireyler günlük hayatta da görev bilinci, duyguların doğru yönetimi anlayışına sahip oldukları için yaşamdan daha fazla doyum elde edebilir.

Tanrıverdi ve arkadaşları (2019)'nın yapmış oldukları çalışmada kişilik özellikleri, duygusal zeka, kariyer uyum yeteneği ve turizmde kariyer yapma isteği arasındaki ilişkiler analiz edilmiştir. Araştırmadan elde 


\section{E. Keskin - Ö. Yayla - F. Aktaş 12/3 (2020) 2985-2995}

edilen bulgular ışığında bireylerde duygusal zekanın alt boyutlarını ifade eden dışadönüklük, empati, pozitif duyguların yönetimi gibi bazı olguların yüksek olması durumunda bireylerde geleceğe yönelik kaygı durumunun azaldığı tespit edilmiştir. Elde edilen bu bulgu neticesinde kaygı durumu azalan bireyler mesleki yaşantılarında kendilerini rahat hissederek geleceğe yönelik kariyer hedeflerini kendilerinden emin bir şekilde belirleyebilir. Mesleki yaşantılarında kaygı, korku gibi ruh hali durumlarını daha az yaşayan kişiler özel yaşantılarında da kendilerini daha huzurlu hissedebilirler. Canbek (2019) rol belirsizliği ile rol çatışmasının işten ayrılma niyeti üzerinde etkisinde duygusal zekanın rolünü incelemiş fakat istatistiki olarak anlamlı bir etki tespit edememiştir. Özkan (2017) yapmış olduğu çalışmada duygusal zeka, psikolojik sağlamlık ve kariyer geleceği arasındaki ilişkileri incelemiştir. Çalışmanın bulguları incelendiğinde duygusal zeka düzeyi yüksek olan bireylerin kariyer geleceği algısının da daha yüksek olduğu belirlenmiştir. Duygusal zekanın, ruhsal iyi olma hali, sosyal açıdan dışa dönüklük, öz kontrol gibi bir takım yapıcı mekanizmaları ortaya çıkarması kişilerin kariyer planları kurarken daha iyimser bir ruh halinde olmasını sağlar. Bundan dolayı duygusal zekası yüksek kişiler günlük hayattaki olaylara karşı daha iyimser ve pozitif bir ruh hali takınarak yaşamdan daha fazla doyum hissederler. Genç ve arkadaşları (2016) çalışmalarında, otel işletmelerinde duygusal zeka durumunun iş stresi ve iş yaşam dengesi üzerindeki etkilerini ele almışlardır. Araştırma sonucunda çalışanların kendi duygu durumlarının farkında olmasının önemli olduğu, bunun yanında yöneticilerin ve takım arkadaşlarının motive edici davranışlarının kişilerde işe olan aidiyet duygusunu arttırdığı çalışmadan tespit edilen önemli bulgular arasındadır. İş yaşamında bireylerin motive edilmesinin kariyer uyum sürecinde de olumlu etkileri olduğu gözlemlenmektedir.

Sener ve arkadaşları (2009) gerçekleştirmiş oldukları çalışmada duygusal zekanın iş hayatına etkisini incelemişlerdir. Bulgulara göre duyguları anlamlandırabilmek, bireylerde empati gücünün fazla olması, iş yaşamında kişileri motive eden faktörlerdir. Duygusal zekası yüksek bireylerin duygu ve düşünceleri anlama becerisi yüksek olduğu için bu kişiler hem kariyer odaklı iş yaşamında hem de özel yaşamında avantajlı bir konuma sahip olabilmektedir. Zeidner ve arkadaşları (2004) yapmış oldukları çalışmada duygusal zeka kavramının iş yaşamına olan etkisini incelemişlerdir. Çalışmadan elde edilen bulgular neticesinde duygusal zekanın kaygı ve endişe durumlarının yönetimi açısından önemli olduğu, kariyer planlaması yapılırken yenilikçi ve cesur kararların verilmesinde pozitif yönde etkileri olduğu ortaya konulmuştur. Duygusal zeka kavramının işletmeler tarafından daha etkin bir şekilde ele alınması çalışanların kendilerini yaptıkları işe daha çok vermeleri ve çalışma ortamları içerisinde kendilerine yeni kariyer planları oluşmaları açısından önemlidir. Çalıştıkları iş yerinde planlarına ulaşmayı hedefleyerek, özveriyle çalışan bireyler, gelecek kariyer planlarını önceden belirledikleri için gündelik yaşamlarında da yaşam doyumuna ulaşırlar.

Creed ve Hughes (2013) yürütmüş oldukları çalışmada duygu durumu ve kariyer gelişimi arasındaki ilişkileri ele almışlardır. Çalışmadan elde edilen sonuçlara göre insanlar duygularını yeterince kontrol altında tutamadıkları zamanlarda kariyer hedeflerini ertelemekte ya da tamamen ortadan kaldırmaktadır. Bireylerin iş yaşamındaki hedeflerine ulaşmada duygusal zekalarını kullanarak kariyer planları belirlemeleri fırsat durumları yaratmada kişileri olumlu anlamda etkilemektedir. Kariyer planları çizilmiş, geleceğinden kaygı duymayan kişiler günlük yaşamlarında da kendilerini daha konforlu hissederek yaşamdan daha fazla doyum sağlamaktadır. Law ve arkadaşları (2008) yapmış oldukları çalışmada duygusal zekanın iş yaşamı ve yaşam memnuniyeti üzerindeki etkilerini incelemiştir. Çalışmadan elde edilen veriler ışığında kişilerde duygusal zeka düzeyinin işe yatkın olma durumu ve iş memnuniyeti üzerinde olumlu etkileri tespit edilmiştir. Bölükbaşı ve Kırdök (2019) yapmış oldukları çalışmada kariyer adaptasyonu ve yaşam doyumu ilişkisini ele almışlardır. Araştırmadan elde edilen bulgular dahilinde kariyer uyumunun yaşamı anlamlı hale getirmekteki etkisinin güçlü olduğu, gelecekteki hedef meslek seçimlerinde öngörücü bir rol üstlendiği ve kariyer beklentilerinin artması halinde bireylerin yaşamdan daha fazla doyum elde edebileceği sonucuna ulaşılmıştır. Yaşam doyumuna yönelik benzer şekilde Toker ve Kalıpçı (2020) iş yaşam dengesi ile yaşam doyumu arasında ilişki tespit etmiştir.

Creed ve arkadaşları (2002) araştırmalarında duygusal zeka kullanımında iyimser ve kötümser bakış açılarının kariyer uyumu üzerindeki etkilerini incelemişlerdir. Araştırmada duygusal zekası yüksek bireylerin geleceğe yönelik kariyer hedeflerini iyi inşa ettikleri belirlenmiştir. Ayrıca bireylerde kariyer hedeflerine yönelik duygu durumlarının iyimser olması hayata dair olumlu kazanımlar elde ederek yaşamdan doyum elde etmelerini kolaylaştırdığı da elde edilen sonuçlardandır. Dulewicz ve Higgs (2000) çalışmalarında duygusal zeka kavramının gelişimini ve kökenlerini incelemişlerdir. Çalışmanın bulguları dahilinde duygusal 
zekası yüksek bireyler diğer bireylere karşı rekabet avantajı geliştirerek kariyer basamaklarında daha hızlı bir şekilde yükselirler. Kariyer hedefleri doğrultusunda duygularını kullanabilen kişiler kendi öz farkındalıklarını yarattıkları için aynı zamanda yaşam başarısı ve doyumuna da erişmiş olurlar.

Palmer ve arkadaşları (2002) yapmış oldukları çalışmada duygusal zeka ve yaşam doyumu arasındaki ilişkiyi incelemişlerdir. Çalışmadan elde edilen veriler doğrultusunda duygusal zekanın mesleki yaşantılarda yeterli seviyede var olması durumunda bireylerin kariyer odaklı düşünme ve ruh halinde psikolojik iyi oluş durumu gerçekleştiği gözlemlenmiştir. Mesleki başarı ve hedeflerin olumlu olarak geliştiği durumlarda bireylerin hayata karşı olan duygusal eksiklikleri de azalarak yaşamdan daha fazla doyum elde etme olasılıkları artmaktadır. Oğan ve Cinel (2019) çalışmalarında iş hayatındaki duygusal zeka durumu ve kariyer uyum yeteneği ilişkisini incelemişlerdir. Duygusal zekanın iş hayatı içerisinde bireylere kişilerarası iletişimlerinde uyumlu ve anlayışlı olabilme, enerjilerini doğru bir şekilde yönetebilme beceresi kazandırdığı gibi pek çok tespitte bulunulmuştur. Aksaraylı ve Özgen (2008) yapmış oldukları çalışmada kariyer gelişiminde duygusal zekanın rolünü incelemişlerdir. Yapılan çalışmada iş yaşamında performansı düşük ve memnuniyetsiz olan bireylerin yaşam kalite düzeylerinin de azaldığı belirlenmiştir. Yapılan literatür taraması sonucunda çalışanların duygusal zekalarının kariyer uyumlarını olumlu yönde etkileyebileceği ve kariyer uyumu yaşayan bireylerinde yaşamdan daha fazla doyum alabileceği ifade edilebilir.

\section{METODOLOJI}

Duygular insanların davranışlarında etkili olan önemli unsurlardan birisidir. Kişiliğin oluşmasında ve bireylerin ortaya koydukları hareketlerde duyguların etkili olması işletmelerde duygusal zeka kavramına önem verilmesi gerekliliğini ortaya çıkarmıştır. Bu nedenle işletmelerde çalışan kişilerin sahip olduğu duygusal zekanın ne düzeyde olduğunun tespit edilmesi önemli görülmektedir. Çünkü duygularına hakim olan ve duygusal yönden güçlü olan bireylerin daha başarılı olacakları ve işletmeye katkılarının fazla olacağı yadsınamaz bir gerçektir. Bu nedenle hazırlanan bu çalışma Kapadokya bölgesinde turizm sektöründe görev yapan bireylerin duygusal zekaları, kariyer uyumları ve yaşam doyumları arasındaki ilişkileri tespit etmeyi hedeflemiştir. Bu hedef doğrultusunda aşağıda yer alan 2 hipotez test edilmiştir.

H1: Duygusal zekanın kariyer uyumu üzerinde pozitif ve anlamlı etkisi vardır.

H2: Kariyer uyumunun yaşam doyumu üzerinde pozitif ve anlamlı etkisi vardır.

\subsection{Veri Toplama Yöntemi}

Hazırlanan bu çalışmada nicel araştırma yönteminden faydalanılmıştır. Analizler için gerekli olan veriler anket tekniğinden faydalanılarak elde edilmiştir. Araştırmada kullanılan anketlerin uygulanabilirliği için Nevşehir Hacı Bektaş Veli Üniversitesinden 08.06.2020 tarihli 12 toplantı numaralı etik kurul raporu alınmıştır. Araştırma kapsamında, duygusal zekayı ölçmek için Demir (2009)' in MSCEIT, EQ-I ve ECI modellerine bağlı kalarak geliştirdiği 4 boyut ve 12 ifadeden oluşan duygusal zeka ölçeğinden, kariyer uyumunu ölçmek için Savickas ve Porfeli (2012) tarafından geliştirilen 4 boyut ve 24 ifadeden oluşan kariyer uyum ölçeğinden ve son olarak da yaşam doyumunu ölçmek için ise Diener ve arkadaşları (1985) tarafından geliştirilen, Dağlı ve Baysal (2016) tarafından Türkçeye uyarlaması yapılan tek boyut ve 5 ifadeden oluşan yaşam doyumu ölçeğinden faydalanılmıştır.

\subsection{Evren ve Örneklem}

Çalışmanın evrenini Kapadokya'da turizm sektöründe çalışan kişiler oluşturmaktadır. Çalışma esnasında veriler, tesadüfi örnekleme yöntemlerinden birisi olan basit kümeleme örneklem tekniğiyle Haziran-Temmuz 2020 aralığında, sektörde çalışan kişilere yüz-yüze anket ve e-anket uygulanarak toplanmıştır. Toplamda 600 kişi ile iletişime geçilmiş, 373 dönüt sağlanmıştır.

\subsection{Araştırma Bulguları}

Çalışmada ilk olarak katılımcıların demografik özelliklerine yönelik bulgular incelenmiştir. Elde edilen veriler doğrultusunda katılımcıların \% 53,9'unun erkek, \%59,7'sinin bekar, \%62,5'inin lisans mezunu ve \%68,3'ünün 18-28 yaş aralığında olduğu belirlenmiştir. Verilen oranlar çalışma katılımcılarına ait en yüksek oranlardır. Demografik özelliklerin belirlenmesinin ardından verilerin normal dağılıma uygun olup olmadığını belirlemek için "çarpıklık ve basıklık" değerlerine bakılmıştır. Tabachnik, Fidell ve Ullman (2007) verilerin 
E. Keskin - Ö. Yayla - F. Aktaş 12/3 (2020) 2985-2995

çarpıklık ve basıklık değerlerinin -1,5 ile 1,5 arasında olması gerektiğini söylemiştir. Ölçeklere ait maddeler incelendiğinde çarpıklık ve basıklık değerlerinin -1,5 ile 1,5 aralığında olduğu ve değişkenlere ait verilerin çoklu normal dağılım gösterdiği tespit edilmiştir. Çarpıklık ve basıklık değerlerinin uygunluğu belirlendikten sonra ölçeklerin faktör yüklerine ve güvenirliklerine yönelik analizler gerçekleştirilmiştir.

Tablo 1. Ölçeklere İlişkin Faktör Yük Dağılımları, Çarpıklık-Basıklık Değerleri ve Güvenirlik Katsayıları

\begin{tabular}{|c|c|c|c|c|c|}
\hline Faktörler / Maddeler & $\begin{array}{l}\text { Faktör Yükleri } \\
\text { AFA/ DFA }\end{array}$ & Çarpıklık & Basıklık & CA & $\mathrm{CR}$ \\
\hline Duygusal Zeka(DZ) & & & & ,769 & 827 \\
\hline \multicolumn{6}{|l|}{ DZ Faktör: Duyguları Algılama(DAL) } \\
\hline $\begin{array}{l}\text { Duygular yaşamımı oluşturan } \\
\text { unsurlardan biridir }\end{array}$ & $670 /, 670$ & $-1,165$ & 1,411 & & \\
\hline $\begin{array}{l}\text { Deneyim kazandıkça duygularımın } \\
\text { farkına varırım }\end{array}$ &, $685 /, 547$ & $-1,226$ & 1,356 & & \\
\hline $\begin{array}{l}\text { Duygularım farklı düşünebilmemi } \\
\text { sağlar }\end{array}$ & ,717/,670 & $-1,133$ & 1,295 & & \\
\hline \multicolumn{6}{|l|}{ DZ Faktör: Duyguları Anlama (DAN) } \\
\hline $\begin{array}{l}\text { İnsanların davranışlarından } \\
\text { duygularını anlarım }\end{array}$ & ,782/,498 & $-1,134$ & 1,450 & & \\
\hline $\begin{array}{l}\text { Duygularımın neden değiştiğini } \\
\text { bilirim }\end{array}$ & $726 /, 680$ &,- 857 & ,510 & & \\
\hline $\begin{array}{l}\text { Duyguları anlamak, doğru karar } \\
\text { vermemi sağlar }\end{array}$ & $660 /, 734$ &,- 968 & 690 & & \\
\hline \multicolumn{6}{|l|}{ DZ Faktör Duyguları Kullanma (DK) } \\
\hline $\begin{array}{l}\text { Duygular çalışma yaşamında başarımı } \\
\text { etkiler }\end{array}$ & $612 /, 479$ & $-1,105$ & ,566 & & \\
\hline $\begin{array}{l}\text { Olumlu duyguya sahipken olaylara da } \\
\text { olumlu yaklaşırım }\end{array}$ & $691 /, 721$ & $-1,227$ & , 1,277 & & \\
\hline $\begin{array}{l}\text { Duygularımı kendimi motive etmek } \\
\text { için kullanırım }\end{array}$ &, $577 /, 600$ &,- 956 & 761 & & \\
\hline
\end{tabular}

\begin{tabular}{llll}
\hline DZ Faktör Duyguları Yönetme (DY) & & & \\
\hline Duygularımı kontrol edebilirim &, $892 /, 256$ &,- 381 &,- 600 \\
\hline $\begin{array}{l}\text { Duygularımı duruma göre } \\
\text { yönlendirebilirim }\end{array}$ &, $880 /, 834$ &,- 516 &,- 267 \\
\hline $\begin{array}{l}\text { İnsanlar hakkında hep olumlu } \\
\text { düşünürüm }\end{array}$ &, $978 /, 833$ &, 227 &,- 637 \\
\hline
\end{tabular}

Toplam Açılanan Varyans: \%62,51

Kaiser-Meyer-Olkin Örneklem

Yeterliliği Ölçüsü: ,799

Bartlett Küresellik Testi: 1136,468

Serbestlik derecesi: 66 p değeri:,000

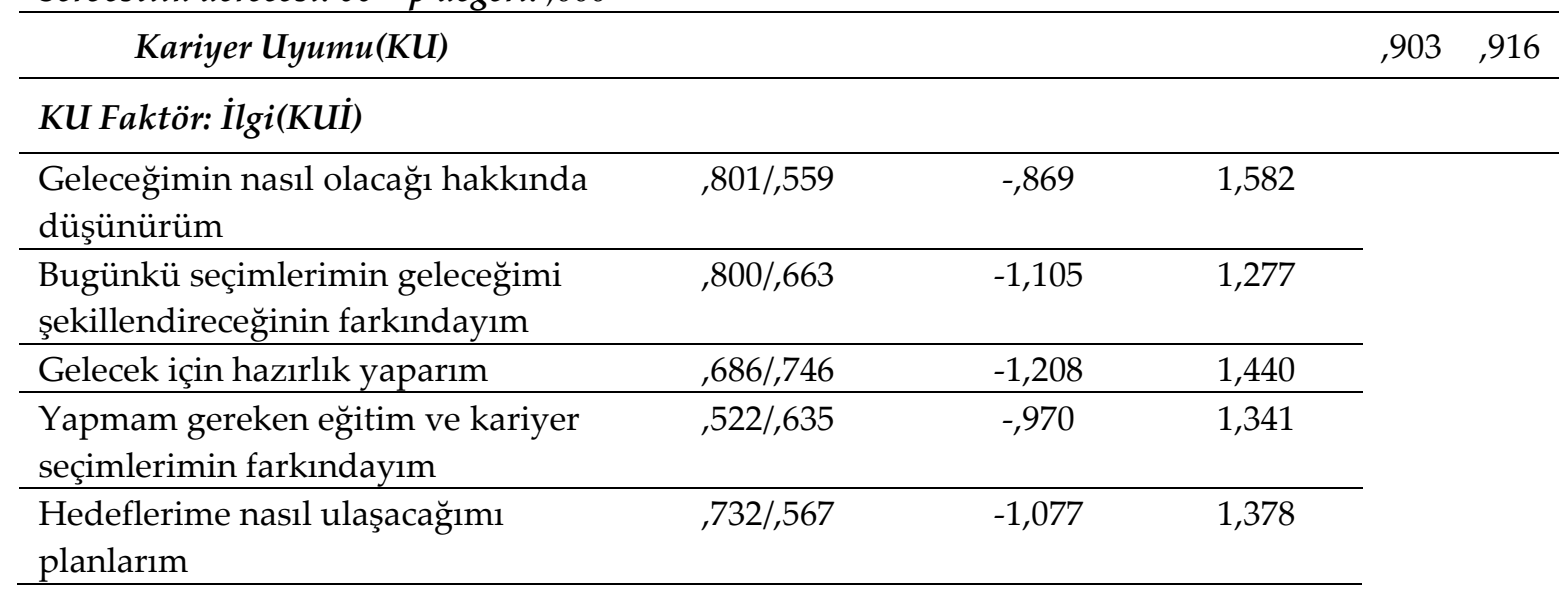


E. Keskin - Ö. Yayla - F. Aktaş 12/3 (2020) 2985-2995

\begin{tabular}{|c|c|c|c|}
\hline Kariyerim hakkında endişeliyim &, $564 /, 071$ &,- 034 & $-1,038$ \\
\hline \multicolumn{4}{|l|}{ KU Faktör: Kontrol (KUK) } \\
\hline Olaylar karşısında iyimser kalırım &, $532 /, 284$ &,- 546 & 092 \\
\hline Kararlarımı kendim veririm & ,771/,470 &,- 999 & 1,422 \\
\hline Yaptığım işlerde sorumluluk alırım & ,489/,712 & $-1,025$ & 1,311 \\
\hline İnandığım şeyleri yaparım & ,767/,537 &,- 964 & 1,113 \\
\hline Kendime güvenirim &, $472 /, 579$ & $-1,121$ & 1,327 \\
\hline Benim için doğru olanı yaparım & ,619/,671 & $-1,120$ & 1,167 \\
\hline \multicolumn{4}{|l|}{ KU Faktör: Merak (KUM) } \\
\hline Etrafımı keşfederim &, $575 /, 658$ &,- 797 & 1,054 \\
\hline Kendimi geliştirmek için fırsat ararım &, $524 /, 676$ & $-1,040$ & 1,189 \\
\hline $\begin{array}{l}\text { Seçim yapmadan önce seçenekleri } \\
\text { araştırırım }\end{array}$ &, $541 /, 540$ & $-1,020$ & 1,277 \\
\hline $\begin{array}{l}\text { Bir şey yaparken farklı yolları } \\
\text { araştırırım }\end{array}$ & ,442/,658 &,- 984 & 1,424 \\
\hline $\begin{array}{l}\text { Aklımdaki soruları derinlemesine } \\
\text { araştırırım }\end{array}$ & 497/,672 &,- 820 & 1,230 \\
\hline Yeni çıkacak fırsatları takip ederim &, $442 / 528$ &,- 971 & 1,241 \\
\hline \multicolumn{4}{|l|}{ KU Faktör: Güven (KUG) } \\
\hline $\begin{array}{l}\text { Görevlerimi verimli bir şekilde yerine } \\
\text { getiririm }\end{array}$ & 631/,533 &,- 870 & ,781 \\
\hline İşleri iyi yapmaya özen gösteririm & ,715/,747 &,- 924 & ,353 \\
\hline Yeni beceriler öğrenmeye çalışırım & ,710/,775 &,- 944 & ,742 \\
\hline Yeteneğimi geliştirmek için çalışırım &, $672 /, 606$ &,- 745 & 231 \\
\hline $\begin{array}{l}\text { Önüme çıkan engelleri aşmaya } \\
\text { çalışırım }\end{array}$ &, $581 /, 651$ & $-1,011$ & 1,394 \\
\hline Sorunları çözmeye çalışırım & ,614/584 &,- 900 & 1,125 \\
\hline
\end{tabular}

Toplam Açıklanan Varyans: \%51, 420

Kaiser-Meyer-Olkin Örneklem

Yeterliliği Ölçüsü: ,888

Bartlett Küresellik Testi: 3313,901

Serbestlik derecesi :276

p değeri: ,000

Yaşam Doyumu(YD)

$, 840 \quad, 876$

\begin{tabular}{llcl}
\hline İdeallerime yakın bir yaşantım vardır &, $674 /, 563$ &,- 572 &,- 394 \\
\hline Yaşam koşullarım mükemmeldir &, $831 /, 765$ &, 111 &,- 687 \\
\hline Yaşamımdan memnunum &, $860 /, 847$ &,- 516 &,- 424 \\
\hline $\begin{array}{l}\text { Şimdiye kadar yaşamdan istediğim } \\
\text { önemli şeylere sahip oldum. }\end{array}$ &, $849 /, 819$ &,- 326 &,- 857 \\
\hline $\begin{array}{l}\text { Tekrar dünyaya gelsem hayatımdaki } \\
\text { hemen hemen hiçbir şeyi değiştirmezdim }\end{array}$ &, $687 /, 599$ &, 179 & $-1,107$ \\
\hline
\end{tabular}

Toplam Açıklanan Varyans: \%61,545

Kaiser-Meyer-Olkin Örneklem

Yeterliliği Ölçüsü: , 827

Bartlett Küresellik Testi: 769,043

Serbestlik derecesi: 10

p değeri: ,000

Tablo 1'deki bulgular incelendiğinde ölçeklere ait örneklem sayısının analiz yeterliliğini belirlemek adına KMO değerlerine bakılmış ve değerlerin 0,60' dan yüksek çıtı̆̆ $\breve{g}_{1}$ ve Bartlett's test sonuçlarının anlamlı olduğu belirlenmiştir. Elde edilen sonuçlar dahilinde KMO değerinin 0,60'tan yüksek olması ve Barlett testinin anlamlı çıkması (Büyüköztürk, 2002), verilerinin faktör analizi için uygun olduğunu göstermiştir. 
E. Keskin - Ö. Yayla - F. Aktaş 12/3 (2020) 2985-2995

Ölçek maddelerinin faktör yükleri incelendiğinde maddelerin yer aldıkları faktörlerdeki yük değerlerinin 0,30 ve üzerinde olması uygun bir ölçü olarak kabul edilmektedir (Kline, 1994). Tablo 1 incelendiğinde duygusal zeka ölçeğinin duyguları yönetme boyutundaki ilk maddenin, kariyer uyumu ölçeğindeki ilgi boyutunda yer alan 6. maddenin ve kontrol boyutundaki ilk maddenin faktör yüklerinin oldukça düşük olduğu belirlenmiştir. Bu nedenle bu maddeler ölçekten çıkarılmıştır.

Açıklayıcı ve doğrulayıcı faktör analizlerinin ardından ölçeklerin güvenirliklerine yönelik analizler yapılmıştır. Ölçeklerin iç tutarlılık güvenirliğini tespit etmek amacıyla Cronbach Alfa (CA) ve birleşik güvenirlik (CR) değerleri incelenmiştir. İlgili ölçeklerin Cronbach Alfa ve birleşik güvenirlik değerlerinin 0,76 üzerinde ve kabul edilebilir düzeyde olduğu (Hair, vd., 2005; Kalaycı, 2009) belirlenmiştir. Bu durum ölçek yapısının güvenilir olduğunu ortaya koymuştur.

Tablo 2. Ölçeklere İlişkin Korelasyon Katsayıları, Standart Sapma ve Ortalama Değerleri

\begin{tabular}{cccccc}
\hline Ölçekler & 1 & 2 & 3 & ORT & SS \\
DZ(1) & - &, 425 &, 184 & 3,85 &, 916 \\
KU(2) &, 425 & - &, 223 & 4,22 &, 540 \\
YD(3) &, 184 &, 223 & - & 3,14 &, 453 \\
\hline
\end{tabular}

Ölçeklere yönelik açıklayıcı-doğrulayıcı faktör analizleri ve güvenirliklerinin belirlenmesinden sonra duygusal zeka (DZ), kariyer uyumu (KU) ve yaşam doyumu (YD) arasındaki korelasyon ilişkileri tespit edilmiştir. Büyüköztürk (2002) korelasyon katsayısının -1 ile +1 arasında bir değer alabileceğini belirtmiştir. Tablo 2 incelendiğinde ölçekler arasında pozitif yönlü korelasyon ilişkilerinin olduğu görülmekle birlikte en yüksek korelasyon ilişkisinin DZ ile KU arasında olduğu tespit edilmiştir.

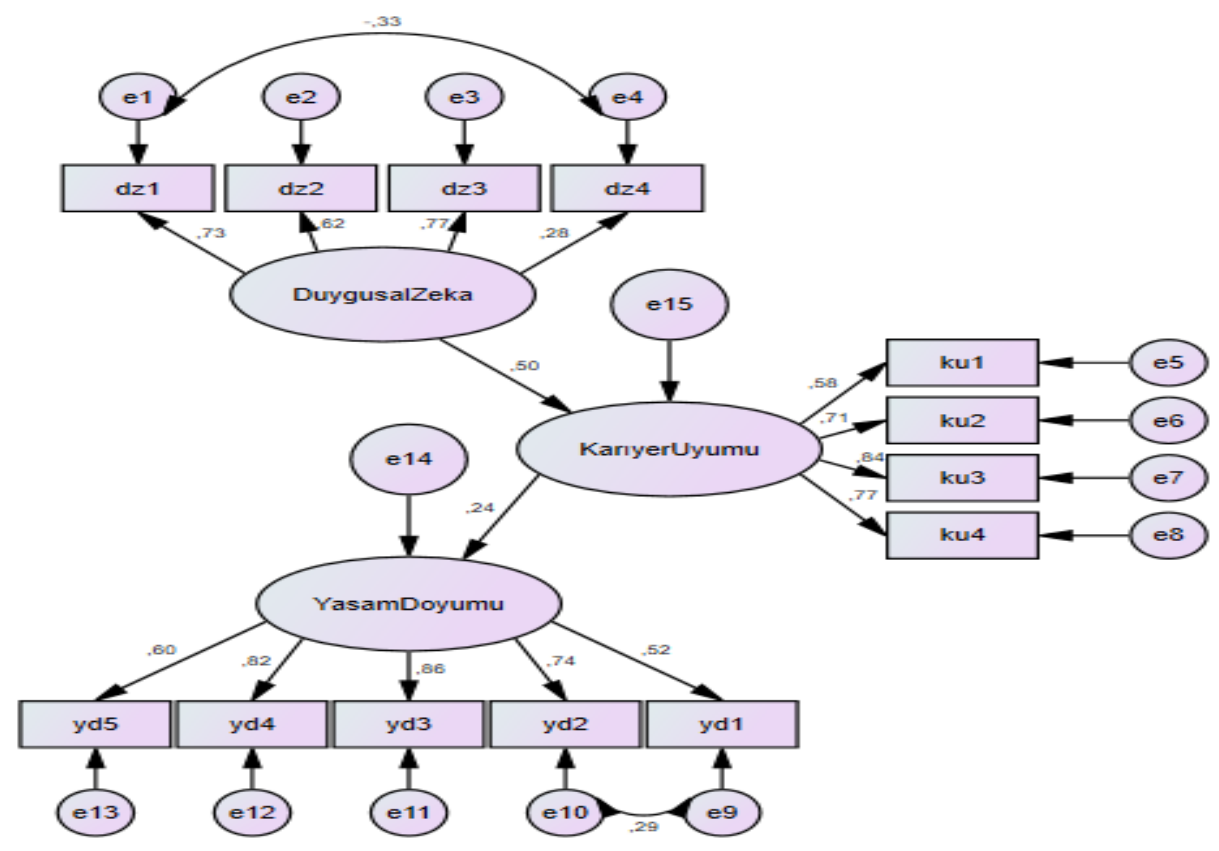

\begin{tabular}{cccccc}
\hline & $\Delta \chi^{2} / \mathrm{df}$ & RMSEA & CFI & NFI & GFI \\
& 2,862 &, 071 &, 935 &, 905 &, 935 \\
\hline İlişkiler & & B & S.H & P & Hipotezler \\
DZ----> KU & &, 502 &, 053 & $* * *$ & Kabul \\
KU----->YD & &, 235 &, 105 & $* * *$ & Kabul \\
\hline
\end{tabular}

$\mathrm{p}<, 001$

Şekil 1: Model Analizi

Korelasyon analizlerinden sonra hipotez testlerine yönelik analizlere geçilmiştir. Şekil 1 incelendiğinde modele yönelik uyum iyiliği değerleri görülmektedir ( $\Delta \chi^{2} / \mathrm{df:} 2,862$, RMSEA: ,071, CFI: ,935, NFI: ,905, GFI: ,935). Hair ve arkadaşlarına (2005) göre elde edilen değerlerin kabul edilebilir değer aralığında olduğu söylenebilir. 
Hipotezlere yönelik analiz sonuçları incelendiğinde Kapadokya bölgesinde turizm sektöründe çalışanların duygusal zeka düzeyleri ile kariyer uyumları arasında, kariyer uyumlarıyla da yaşam doyumları arasında anlamlı ve pozitif yönlü ilişkilerin olduğu saptanmıştır. Elde edilen bulgular doğrultusunda H1 ve H2 hipotezleri kabul edilmiştir.

\section{SONUÇ ve TARTIŞMA}

Turizm sektörü son 20 yılda en fazla gelişim gösteren sektörlerin başında gelmektedir (Temeloğlu ve Aksu, 2016). Bu gelişim turizm profesyonellerinin ihtiyaç duyduğu beceri seviyelerinde de önemli bir değişiklik meydana getirmiştir (Kandampully ve Suhartanto, 2000; Otting, vd., 2009; Karakuş vd., 2018). Literatür incelendiğinde, turizm profesyonellerinin teknik ve operasyonel becerilerinin yanında duygusal becerilerinin de önemli bir yer tuttuğu anlaşılmaktadır (Lashley, 2008). Zira, turizm sektörü hizmet tabanlı bir sektördür ve turizm çalışanları sürekli birlikte çalıştıkları kişiler ve müşteriler ile iletişim halindedir. Bu noktada sektör çalışanları sürekli olarak duygularını kontrol altında tutabilmelidir (Scott-Halsell, vd., 2011). Dolayısıyla, turizm sektör çalışanlarının en az teknik ve operasyonel becerileri kadar duygusal zekalarının önemli bir rolünün olduğuna dair literatürde bir görüş birliği vardır. Bu bilgiden hareketle bu araştırma Kapadokya bölgesinde konaklama sektöründe çalışan turizm personelinin duygusal zekalarını tespit etmek, söz konusu değişkenin kariyer uyumu üzerine ve kariyer uyumunun da yaşam doyumu üzerine etkisini belirlemek amacıyla yapılmıştır.

Çalışma sonuçları, çalışanların duygusal zekalarının kariyer uyumlarını olumlu bir şekilde etkilediğini doğrulamıştır. Nelson ve Low (2003), kişilerin duygusal zekalarının kariyer uyumlarına olumlu yönde etki edeceğini savunmaktadır. Çalışmada duygusal zeka boyutundaki bir birimlik artışın kariyer uyumunu 0.50 birimlik arttırdığı tespit edilmiştir. Tanrıverdi, vd., (2019)'nin yapmış olduğu çalışmada öğrencilerin duygusal zekalarının kariyer uyumlarını pozitif yönde etkilediğine yönelik bulgular mevcuttur. Çalışma bulguları değerlendirildiğinde otel çalışanlarında da benzer sonuçlar elde edilmiştir. Bu bağlamda ulaşılan sonuç literatürle paralellik göstermektedir. Sonuçlar ışığında insan kaynakları departman yöneticilerinin özellikle iş gören seçim süreçlerinde entelektüel zeka testlerinin yanında duygusal zeka testlerini de kullanmaları kariyer uyumlarını gerçekleştirebilecek personelin işe alınmasına katkı sağlayacaktır.

Çalışma sonuçlarından elde edilen veriler ışı̆̆ında literatürde doldurulan önemli boşluklardan bir diğeri kariyer uyumunun yaşam doyumuna olan etkisidir. Kariyer uyumu bireylerin kariyer süreçlerinde karşılaşabilecekleri problemlere hazırlıklı olması ve problemlerle baş edebilme yeteneği olarak ifade edilmektedir (Savickas, 1997). Çalışmada, kariyer uyumu ile yaşam doyumu arasında pozitif yönlü bir ilişki tespit edilmiştir. Bir diğer ifade ile turizm çalışanlarının kariyer uyumları arttıkça yaşam doyumları yükselmektedir. Çalışma sonuçlarında kariyer doyumunda meydana gelen bir birimlik artışın yaşam doyumunu 0.24 oranında arttırdığı görülmektedir. Bu sonuç literatürün ulaştığı bilgilerle örtüşmektedir. Bölükbaşı ve Kırdök (2019) yapmış oldukları çalışmada lise öğrencilerinde kariyer uyumlarının yaşam doyumlarını önemli ölçüde etkilediğini saptamıştır. Bu bulgular ışığında turizm çalışanlarının yaşam doyumlarının sağlanabilmesi için kariyer uyumlarını geliştirmeye yönelik çalı̧̧maların yapılması önerilmektedir. Otellerin insan kaynakları departmanlarında çalı̧makta olan yöneticilerin belli aralıklarla personelin kariyer uyumlarını ölçmesi ve yürütülecek rehberlik faaliyetleri kariyer uyumlarına olumlu yönde etki edecektir.

Araştırmada Kapadokya bölgesindeki turizm çalışanlarının duygusal zekalarının kariyer uyumuna ve kariyer uyumunun da yaşam doyumuna etkileri araştırılmıştır. Gelecek çalışmalarda farklı meslek grupları için benzer çalışmalar yapılarak sonuçları bu çalışma ile mukayese edilebilir. Bunun yanında, turizm çalışanlarının iş yerlerindeki departmanları söz konusu etkinin şiddetini değiştirebilir. Ayrıca, iş tatmininin ilgili değişkenlerle doğrudan ve dolaylı etkileri incelenebilir. İlerleyen çalışmalarda çalışanların demografik özellikleri ile duygusal zeka, kariyer uyumu ve yaşam doyumu arasındaki farklılıkların tespiti literatürde var olan boşluğun doldurulmasına katkı sağlayacağı düşünülmektedir.

\section{KAYNAKÇA}

Akçay, C., \& Çoruk, A. (2012). Çalışma yaşamında duygular ve yönetimi: Kavramsal bir inceleme. Journal of Policy Analysis in Education, 1(1), 3-25. 
E. Keskin - Ö. Yayla - F. Aktaş 12/3 (2020) 2985-2995

Aksaraylı, M. \& Özgen, I. (2008). Akademik kariyer gelişiminde duygusal zekanın rolü üzerine bir araştırma. Ege Akademik Bakış, 8(2), 755-769.

Arslan, E. (2020). Çalışanların Paraya Olan Tutum, Kariyer Bağlılı̆̆ı ve Kariyer Tatmin Düzeyleri Arasındaki İlişki: Otel İşletmelerinde Bir Araştırma, İşletme Araştırmaları Dergisi, 12 (2), 1475-1488.

Ashkanasy, M. N., Hartel, E.J.C. \& Daus, S. C. (2002). Diversity and emotion: The new frontiers in organizational behavior research. Journal of Management, 28(3), 307-338.

Bölükbaşı, A., \& Kırdök, O. (2019). The mediating role of future orientation in the relationship between career adaptability and life satisfaction in high school students. Education and Science, 44(200), 77-91.

Büyüköztürk, Ş. (2002). Veri Analizi El Kitabı, Pegem Yayıncılık, Ankara.

Canbek, M. (2019). Rol stresi ile başa çıkmada duygusal zekanın rolü, İşletme Araştırmaları Dergisi, 11 (1), 144159.

Creed, P. A., Patton, W. \& Bartrum, D. (2002). Multidimensional properties of the LOT-R: Effects of optimism and pessimism on career and wellbeing related variables in adolescents. Journal of Career Assessment, $10(1), 42-61$.

Creed, P. A., \& Hughes, T. (2013). Career development strategies as moderators between career compromise and career outcomes in emerging adults. Journal of Career Development, 40, 146-163.

Cote, S. \& Miners, T. H. C. (2006). Emotional intelligence, cognitive intelligence, and job performance. Johnson Graduate School of Management, 51(1): 1-28.

Çakar, U. \& Arbak, Y. (2004). Modern yaklaşımlar ışı̆̆ında değişen duygu-zeka ilişkisi ve duygusal zeka. Dokuz Eylül Üniversitesi Sosyal Bilimler Enstitüsü Dergisi, 6(3), 23-48.

Çeşmeci, N., Çalışkan, N. \& Özsoy, A. (2020). Turizm Rehberliği Öğrencilerinin Bireysel Kariyer Hedefleri ve Mesleğe Yönelik Tutumları, Journal of Tourism and Gastronomy Studies, 8 (2), 852-869.

Dağlı, A. \& Baysal, N. (2016). Yaşam doyum ölçeğinin Türkçe'ye uyarlanması: Geçerlik ve güvenirlik çalışması. Elektronik Sosyal Bilimler Dergisi, 15(59), 1250-1262.

Demir, M. (2009). Konaklama işletmelerinde duygusal zeka, örgütsel sapma, çalışma yaşam kalitesi ve işten ayrılma eğilimi arasındaki ilişkinin analizi. Yayınlanmamış Doktora Tezi. Dokuz Eylül Üniversitesi. Sosyal Bilimler Enstitüsü. İzmir.

Doğan, S. \& Demiral, Ö. (2007). Kurumların başarısında duygusal zekanın rolü ve önemi. Yönetim ve Ekonomi. $14(1), 210-230$.

Dulewicz, V. \& Higgs, M. (2000). Emotional intelligence a review and evaluation study. Journal of Managerial Psychology, 15(4), 341-372.

Ergün, G. S., \& Boz, H. (2017). İşletmelerin İçsel Pazarlama Uygulamaları ve İşgörenlerin İş Tatmini İlişkisi: Konaklama İşletmelerinde Bir Araştırma, Pazarlama İçgörüsü Üzerine Çalı̧̧malar, 1 (1-2), 1-12.

Genç, G.S., Genç, V. \& Gümüş, M. (2016). Otel işletmelerinde duygusal zekanın iş stresi ve iş yaşam dengesi üzerindeki etkisi. Journal of Life Sciences, 6(2/1), 97-112.

Hair, F. Jr. Black, W. C. Babin, B. J. Anderson, R. E. \& Tatham, R. L. (2005), Multivariate Data Analysis, (6th ed.), New Jersey: Prentice Hall.

Kalaycı, Ş. (2009), Spss Uygulamalı Çok Değişkenli İstatistik Teknikleri, Asil Yayın Dağıtım, Ankara.

Kandampully, J. \& Suhartanto, D. (2000). Customer loyalty in the hotel industry: The role of the customer satisfaction and image. International Journal of Contemporary Tourism, 12 (6), 346-351.

Karakuş, Y., Onat, G., \& Yetiş, Ş. A. (2018). Yöneticilerin, aşçların yetkinliklerine yönelik beklentilerinin değerlendirilmesi. Journal of Tourism and Gastronomy Studies, 6(4), 299-321. 
E. Keskin - Ö. Yayla - F. Aktaş 12/3 (2020) 2985-2995

Kendir, H. \& Özkoç, A.G. (2018). Otel İşletmelerinde Çalışanların Kariyer Tatmini ve Kariyer Bağlılı̆̆1 İlişkisinde Öz Yeterliliğin Rolü. Journal of Tourism and Gastronomy Studies, 6(4), 78-112.

Kline, P. (1994). An Easy Guide to Factor Analysis, New York: Routledge.

Lashley, C. (2008). Studying hospitality: Insight from social sciences. Scandinavian Journal of Hospitality and Tourism, 8 (1), 69-84.

Law, S.K., Wong, S.C. \& Huang, H.G., Li, X. (2008). The effects of emotional intelligence on job performance and life satisfaction for the research and development scientists in China. Asia Pacific Journal of Management, 25(1), 51-69.

Mayer, D.J. \& Salovey, P. (1997). What is Emotional Intelligence? in Peter Salovey, Daniel Sluyter (Eds.). Emotional Development and Emotional Intelligence (pp. 3-31). USA: Basic Books.

Nelson, D. B., \& Low, G. R. (2003). Emotional intelligence: Achieving academic and career excellence. New Jersey: Prentice Hall.

Oğan, E. \& Cinel, O.M. (2019). İş hayatında duygusal zeka ve kariyer uyum yeteneği arasındaki ilişki. 19 Mayıs Yenilikçi Bilimsel Yaklaşımlar Kongresi, 27-29 Aralık 2019, Samsun.

Otting, H., Zwall, W., \& Gijselaers, W. (2009). International hospitality students' epistemogical bliefs and conceptions of teaching and learning. Journal of Hospitality and Tourism Education, 21 (3), 44-53.

Özkan, M. (2017). Öğretmen adaylarının psikolojik sağlamlık, duygusal zeka özellikleri, ve kariyer geleceği algıları arasındaki ilişkinin incelenmesi. Yayınlanmamış Yüksek Lisans Tezi. Uludağ Üniversitesi. Bursa.

Palmer, B., Donaldson, C. \& Stough, C. (2002). Emotional intelligence and life satisfaction. Personality and Individual Differences, 33, 1091-1100.

Savickas, M. L. (1997). Career adaptability: An integrative construct for life-span, life-space theory. Career Development Quarterly, 45, 247-259.

Savickas, L. M. \& Porfeli, J. E. (2012). Career adapt-abilities scale: Construction, reliability, and measurement equivalence across 13 countries. Journal of Vocational Behavior, 80(3), 661-673.

Scott-Hallsel, S., Blum, S. C., \& Huffman, L. (2011). From scholl desks to front desks: A comparison of emotional intelligence levels of hospitality undergraduate stundents to hospitality industry professionals. Journal of Tourism, Leisure, Sport \& Tourism Education, 10 (2), 3-13.

Sener, E., Demirel, Ö. \& Sarlak, K. (2009). The effect of the emotional intelligence on job satisfaction, Stud Health Technol Inform. 146, 710-711.

Sy, T., Tram, S., \& O'Hara, A. L. (2006). Relation of employee and manager emotional intelligence to job satisfaction and performance. Journal of Vocational Behavior, 68(3), 461-473.

Tabachnick, B. G. Fidell, L. S. \& Ullman, J. B. (2007). Using Multivariate Statistics, 5. Bask1, Boston, MA, Pearson.

Tanrıverdi, H., Yılmaz, A., Pala, B. \& Ercan, Z. F. (2019). Kişilik özellikleri, duygusal zekâ, kariyer uyum yeteneği ve turizmde kariyer yapma isteği arasındaki ilişkilerin incelenmesi: İstanbul Üniversitesinde turizm işletmeciliği eğitimi alan öğrenciler üzerine bir araştırma. Uluslararası Turizm, İşletme, Ekonomi Dergisi, 3(1), 41-56.

Temeloğlu, E. \& Aksu, M. (2016). Turizm eğitimi alan öğrencilerin kişilik özelliklerinin turizmde kariyer yapma istekleri üzerindeki etkisi: Çanakkale Onsekiz Mart Üniversitesi örneği. Uluslar Arası Sosyal Araştırmalar Dergisi, 9(43), 1513-1521.

Toker, B., Kalıpçı, M. B. (2020). İş-yaşam dengesinin yaşam doyumuna etkisinde işe gömülmüşlüğün aracılık rolü: Konaklama işletmelerinde bir uygulama, İşletme Araştırmaları Dergisi, 12 (1), $888 .-901$

Tuna, A. A. (2017). Kariyer Seçim Faktörleri ve Sektörün Bu Faktörleri Öğrencilere Sunma Düzeyine İlişkin Bir Araştırma, İşletme Araştırmaları Dergisi, 9 (3), 424-442. 
E. Keskin - Ö. Yayla - F. Aktaş 12/3 (2020) 2985-2995

Vatansever Toylan, N. \& Yılmaz, N. (2020). Psikolojik Güçlendirmenin Kariyer Motivasyonuna Etkisinde Yöneticiye Güvenin Aracılık Rolü: İstanbul'daki Otel Çalışanları Üzerine Bir Araştırma, Türk Turizm Araştırmaları Dergisi, 4(1): 15-30.

Wing, F. J., Schutte, S. N. \& Byrn, B. (2006). The effect of positive writingon emotional intelligence and life satisfaction. Journal Of Clinical Psychology, 62(10), 1291-1302.

Yan, İ. (2008). Duygu-zeka ilişkisi ve duygusal zekanın yöneticiler üzerindeki etkilerine yönelik bir araştırma. Yayınlanmamış Yüksek Lisans Tezi. Afyon Kocatepe Üniversitesi Sosyal Bilimler Enstitüsü. Afyon.

Zeidner, M., Matthews, G. \& Roberts, D. R. (2004). Emotional intelligence in the workplace: A critical review, Applied Psychology: An International Review, 53(3), 371-399. 